\title{
The Predictive Role of Professional Concern and Quality of University Life on Attitudes Toward Teaching Profession Derya Atabey*
}

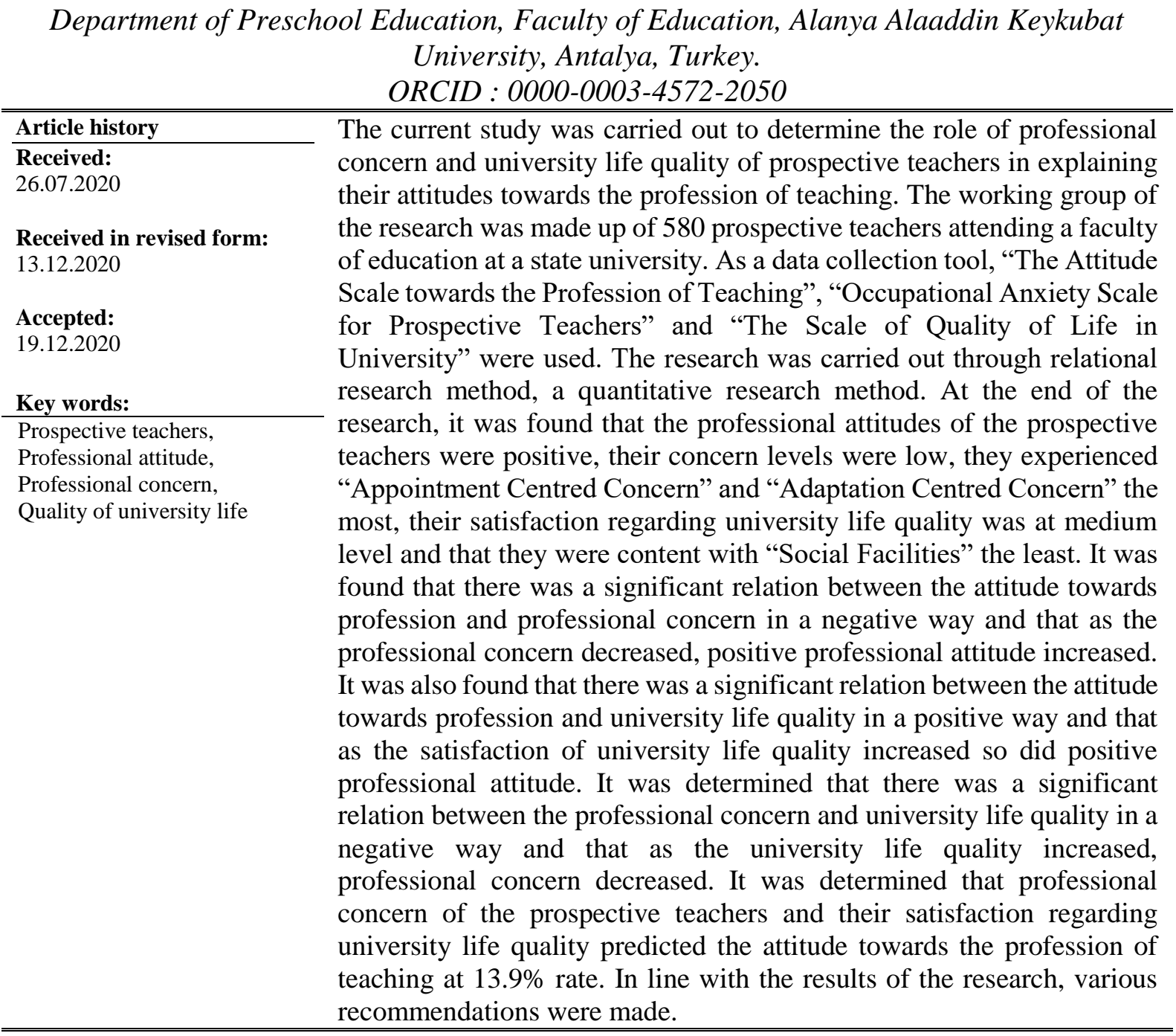

\section{Introduction}

The development level of a country is perceived by means of the importance given to education by that country and through the quality of education. Creating communities with productive, healthy, happy individuals aware of their responsibilities, being beneficial to

\footnotetext{
*Correspondency: deryaatabey1982@gmail.com, derya.atabey@alanya.edu.tr
} 
themselves and others is no doubt realized with the improvement of education. The most significant component of the system of education is teachers. For the sake of meeting the needs of the developing and changing world, increasing the quality at education, determining likely problems and making suggestions for solutions and investigating the teacher training models, a great many studies have been carried out from the past to the current time (Akinbote, 2007; Albareda Tiana et al., 2019; de la Harpe \& Radloff, 1999; Himmat, 2017; König et al., 2017; Kumar \& Azad, 2016; Ries et al., 2016; Sahan, 2016; Stephens et al., 2004; Sykes et al., 2010; Tiwari, 2016).

Profession of teaching is a way of life beyond a profession that could not be performed without love, requiring self-sacrifice, patience and hard working. For that reason, it is essential that teachers have a positive professional attitude as well as professional knowledge and skills. Attitude is a mental, emotional and behavioural reaction and predisposition which an individual develops based on his experience, knowledge, feeling and motives (İnceoğlu, 2010). Upon the review of research conducted in order to determine how predisposition regarding the profession of teaching is, it was found that parents have a negative perspective for the profession of teaching (Audu \& Egharevba, 2016). Prospective teachers are aware of the importance of the profession of teaching and the competencies that they must attain; however, their motivation towards profession decreases since they do not regard the future of their profession positive (Karataş et al., 2017). It was pointed out that the esteem of teachers in the community is at "medium" level and it is the esteem of teachers are affected by the low salary, by some misbehaviours of some teachers and negative news in the media (Atmaca, 2020; Erzen \& Epçapan, 2018). It was also indicated that the expectations of a great majority of the prospective teachers regarding the profession are not met at a desired level and that they have a concern for the future and the profession of teaching is not as an esteemed profession compared to the past (Karamustafaoğlu \& Özmen, 2004). The fact that the running of teacher training institution, value overrun and the structure of the programs are thought to be the major problems in teacher training (Chand, 2015). Regarding the undergoing changes in social, cultural and economic circles, it is thought that there is a need for a fundamental change in teacher education in order that teachers could increase their standards with the changing needs of the community (Singh \& Shakir, 2019). For all these reasons, it is of great importance to train teachers who love their profession, trying to do their best to perform their professions, having a positive professional attitude.

Upon the review of the studies carried out with regard to the professional attitudes of the prospective teachers; significant relations were found between professional attitudes and selfefficacy of the prospective teachers (Demirtaş et al., 2011; Nakip \& Özcan, 2016; Şahin \& Şahin, 2017), student recognition levels (Şahin \& Şahin, 2017), academic success (Uyanık, 2017), professional competence and professional self-esteem (Girgin et al., 2010), their selfconfidence (Manolova Yalçın \& Özgen, 2017), their life-long learning inclinations (Ünal \& Akay, 2017), student control ideologies (Oğuz \& Kalkan, 2011).

As for the factors affecting the professional attitudes of the prospective teachers, it was found that the professional attitudes of the prospective teachers vary depending on their genders (Aydın \& Sağlam, 2012; Gökçe \& Sezer, 2012; Lasek \& Wiesenbergová, 2007; Manolova Yalçın \& Özgen, 2017; Riaz et al., 2015; Uyanık, 2017), the reasons of preference (Aslan \& Köksal Akyol, 2006; Aydın \& Sağlam, 2012; Gökçe \& Sezer, 2012; Nalçacı \& Sökmen, 2016; Özder et al., 2010), mother education level (Aydın \& Sağlam, 2012), the program they are studying (Engin \& Koç, 2014; Gökçe \& Sezer, 2012; Kayhan et al., 2018; Özder et al., 2010), class grades (Manolova Yalçın \& Özgen, 2017; Uyanık, 2017), the institutions they would like 
to work when they start they profession, their academic success (Gökçe \& Sezer, 2012), the status of their parents' being teachers (Lasek \& Wiesenbergová, 2007). When university students complete their education, they would like to have a profession enabling satisfying income which they perform willingly. Even though prospective teachers have different professional attitudes based on various reasons, it is of vital importance that they are graduated with a positive professional attitude in terms of both their individual happiness, life satisfaction, professional success and the responsibility they have for the community.

In the achievement of social development and improvement, teachers have various tasks and responsibilities for the institutions they work for, for families and the community other than their task of education and teaching. The profession of teaching is changing its shell with a sociological, cultural, technological and economic change and the roles and responsibilities of teachers are getting increased (Ansari \& Malik, 2013; Mazmishvili et al., 2019; Mullai, 2017; Ujlakyné Szucs, 2009). The idea of not being able to fulfil these responsibilities, to meet the expectations and a great many reasons could lead prospective teachers to experience professional concern. Fuller (1969) classified this concern of the prospective teachers in three groups as "Self-centred concerns", "Task-centred concerns" and "Student-centred concerns" and pointed out that these concerns intensify on some fields in certain times. It is essential to control this concern that is experienced by prospective teachers and decrease it to the minimum level.

Universities have great tasks and responsibilities in training teachers with a positive professional attitude being able to deal with their concerns. Upon the investigation of the research carried out into university life quality comprising the academic and social experiences, and factors regarding university, expressing positive experiences and satisfaction levels of students with regard to their university life (Eriş \& Anıl, 2016; Kangal, 2012; Sirgy et al., 2007) is observed and it is likely to see the importance of student - teacher communication (Cotten \& Wilson, 2006; Hagenauer et al., 2016; Hagenauer \& Volet, 2014; Hu et al., 2015), the relation between the teaching styles of the lecturers and the academic responsibilities of students (Shaari et al., 2014), the effect of social and academic interaction on learning (Cleveland Innes \& Emes, 2005), social facilities and extra-curricular activities, club and other organizations (Claudia, 2014; Foubert \& Grainger, 2006; Göktaş Kulualp \& Erol, 2018), friendship relations (Picton et al.,2017).

Depending on all the aforementioned issues, the current study is necessary and of importance in terms of determining the professional attitude and professional concern levels and their satisfaction levels regarding the university life quality of the prospective teachers, specifying the relation between professional attitude, professional concern and university life quality, determining the effect of professional concern and university life quality in explaining professional attitude, and of making necessary arrangements in line with the results obtained.

\section{The Purpose of the Research}

The current study was carried out to determine the role of professional concern and university life quality of prospective teachers in explaining their attitudes towards the profession of teaching and in this sense the following questions were tried to be answered:

(1) At what level are the professional attitudes of the prospective teachers?

(2) At what level are the professional concerns of the prospective teachers?

(3) At what level is the satisfaction of the prospective teachers for university life quality? 
(4) Is there a significant relation between professional attitude, professional concern and university life quality?

(5) What is the role of professional concern and university life quality in explaining the attitudes of the prospective teachers towards the profession of teaching?

\section{Method}

\section{The Model of the Study}

As the current study was conducted to investigate the role of professional concern and university life quality in explaining the attitudes of the prospective teachers toward the profession of teaching, relational research method, a quantitative method, was used (Büyüköztürk et al., 2008; Cohen et al., 2007; Walliman, 2017).

\section{Working Group}

The working group was made up of 580 prospective teachers attending to a faculty of education at a state university. The demographic information of the prospective teachers comprising the working group is given in Table 1 and Table 2.

Table 1. The Distribution of The Participant Prospective Teachers Based on their Departments

\begin{tabular}{lll}
\hline Department & $\mathrm{n}$ & $\%$ \\
\hline Elementary Mathematics Teaching & 206 & 35.5 \\
Science Teaching & 115 & 19.8 \\
Preschool Teaching & 95 & 16.4 \\
English Language Teaching & 73 & 12.6 \\
Classroom Teaching & 66 & 11.4 \\
Turkish Language Teaching & 25 & 4.3 \\
Total & 580 & 100.0 \\
\hline
\end{tabular}

As is seen in Table 1, prospective teachers comprising the working group of the research was made up of elementary mathematics teaching at a rate of $35.5 \%$, of science teaching at a rate of $19.8 \%$, of preschool teaching at a rate of $16.4 \%$, of English language teaching at a rate of $12.6 \%$, of classroom teaching at a rate of $11.4 \%$ and of Turkish language teaching at a rate of $4.3 \%$.

Table 2. The Distribution of the Participant Prospective Teachers Based on their Grades

\begin{tabular}{lll}
\hline & $\mathrm{n}$ & $\%$ \\
\hline $1^{\text {st }}$ grade & 258 & 44.5 \\
$2^{\text {nd }}$ grade & 155 & 26.7 \\
$3^{\text {rd }}$ grade & 82 & 14.1 \\
$4^{\text {th }}$ grade & 85 & 14.7 \\
Total & 580 & 100.0 \\
\hline
\end{tabular}

As is given in Table 2, $44.5 \%$ of the prospective teachers comprising the working group of the study was $1^{\text {st }}$ grade students, $26.7 \%$ was $2^{\text {nd }}$ grade students, $14.1 \%$ was $3^{\text {rd }}$ grade students and $14.7 \%$ was $4^{\text {th }}$ grade students.

\section{Data Collection Tool}

As a data collection tool, "The Attitude Scale towards the Profession of Teaching" developed by Üstüner (2006), "Occupational Anxiety Scale for Prospective Teachers" 
developed by Cabı and Yalçınalp (2013) and "The Scale of Quality of Life in University" developed by Doğanay and Sarı (2006) were used.

\section{The Attitude Scale towards the Profession of Teaching}

"The Attitude Scale towards the Profession of Teaching" was developed by Üstüner (2006) in order to determine the attitudes of students studying at a teaching program towards the profession of teaching. The scale is a one dimension, Likert type attitude scale made up of 34 items. The factor loading of the scale varies between .74 and .41 and explains $30 \%$ of factor total variance. Item test correlation values vary between .74 and .42 . The criterion scale validity of the scale is .89. Reliability coefficient is .72. Cronbach Alpha coefficient of consistency is 93 .

\section{Occupational Anxiety Scale for Prospective Teachers}

"Occupational Anxiety Scale for Prospective Teachers" is a Likert type scale developed by Cabı and Yalçınalp (2013) to assess the professional concerns of the prospective teachers. It is made up of 8 sub-dimensions as "Task Centred Concern", "Economic-Social Centred Concern", "Student-Communication Centred Concern", "Colleague and Parent Centred Concern", "Personal Development Centred Concern", "Appointment Centred Concern", "Adaptation Centred Concern" and "School Administration Centred Concern" and of 45 items in total. Corrected item total score correlations of the factors vary between 0.23 and 0.73 while Cronbach Alpha coefficient varies between 0.94 and 0.67.

\section{The Scale of Quality of Life in University}

"The Scale of Quality of Life in University" is a Likert type scale developed by Doğanay and Sar1 (2006) in order to determine the quality of life in university for students. It is made up of 7 sub-dimensions as "Lecturer-Student Communication", "Identity", "Social Facilities", "Involvement in Decisions Making", "Student-Student Communication", "Future" and "Classroom Environment" and of 33 items in total. Cronbach alpha internal consistency coefficient of the scale varies between .73 and .84. Cronbach alpha internal consistency coefficient of the scale in total is .85.

\section{Statistical Analysis of the Data}

The data obtained through "The Attitude Scale towards the Profession of Teaching", "Occupational Anxiety Scale for Prospective Teachers" and "The Scale of Quality of Life in University" was analysed by means of the package program of SPSS 21. Within the content of the descriptive analyses regarding the data, frequency and mean distributions were determined and the relation between the scales was studied through correlation analysis. The predictive power of professional concern and university life quality on attitudes toward the profession of teaching was realized through multiple regression analysis. Significance level was taken as 0.05 .

\section{Findings}

In this part, the findings concerning the statistical analyses realized in line with the aims of the research are given. 
Table 3. Professional Attitude Mean Score

\begin{tabular}{lll}
\hline & $\overline{\mathrm{x}}$ & $\mathrm{sd}$ \\
\hline Professional Attitude & 3.79 & .66 \\
\hline
\end{tabular}

As is given in Table 3, professional attitude mean score of the prospective teachers is 3.79.

Table 4. The Distributions Regarding the Professional Concern Mean Scores

\begin{tabular}{lll}
\hline & $\overline{\mathrm{x}}$ & $\mathrm{sd}$ \\
\hline Task Centred Concern & 3.64 & 0.97 \\
Economic-Social Centred Concern & 3.12 & 1.04 \\
Student-Communication Centred Concern & 3.47 & 1.08 \\
Colleague and Parent Centred Concern & 3.76 & 1.01 \\
Personal Development Centred Concern & 3.49 & 1.23 \\
Appointment Centred Concern & 2.63 & 1.14 \\
Adaptation Centred Concern & 2.63 & 1.14 \\
School Administration Centred Concern & 3.39 & 1.18 \\
Total Professional Concern & 3.44 & 0.84 \\
\hline
\end{tabular}

As is given Table 4, professional concern mean scores of the prospective teachers are 3.44 and they have "Colleague and Parent Centred Concern" ( $\overline{\mathrm{x}}=3.76)$ the least, "Appointment Centred Concern" ( $\overline{\mathrm{x}}=2.63)$ and "Adaptation Centred Concern" $(\overline{\mathrm{x}}=2.63)$ the most.

Table 5. The Distributions Regarding University Life Quality Mean Scores

\begin{tabular}{lll}
\hline & $\overline{\mathrm{x}}$ & $\mathrm{sd}$ \\
\hline Lecturer-Student Communication & 3.18 & .80 \\
Identity & 3.11 & .93 \\
Social Facilities & 2.36 & .85 \\
Involvement in Decisions Making & 2.85 & .67 \\
Student-Student Communication & 2.81 & .79 \\
Future & 2.65 & 1.01 \\
Classroom Environment & 2.98 & .84 \\
Total University Life Quality & 2.85 & .51 \\
\hline
\end{tabular}

As is shown in Table 5, the mean scores of the prospective teachers regarding their university life quality satisfaction are 2.85 and the dimension they are least satisfied is at "Social Facilities" ( $\overline{\mathrm{x}}=2.36)$.

As is given in Table 6, it was found that there was a significant negative relation at low level between "Task Centred Concern" and "Lecturer - Student Communication" sub-dimension ( $\mathrm{r}=$ -.178), a significant negative relation at low level between "Identity" sub-dimension ( $\mathrm{r}=-.185)$, a significant negative relation at low level between "Student - Student Communication" subdimension $(\mathrm{r}=-.092)$, a significant negative relation at low level between "Future" subdimension ( $\mathrm{r}=-.097)$, a significant negative relation at low level between "Classroom Environment" sub- dimension ( $\mathrm{r}=-.091)$, a significant negative relation at low level between "University Life Quality" ( $\mathrm{r}=\mathrm{-} .155)$ and a significant negative relation at medium level between "Attitude towards the Profession of Teaching" $(\mathrm{r}=-.332)$.

It was found that there was a significant negative relation at low level between "Economicsocial Centred Concern" and "Lecturer - Student Communication" sub-dimension $(\mathrm{r}=-, 169)$, a significant negative relation at low level between "Identity" sub-dimension $(\mathrm{r}=-.254)$, a significant negative relation at low level between "Social Facilities" sub- dimension ( $\mathrm{r}=-.094)$, a significant negative relation at low level between "Student - Student Communication" subdimension ( $\mathrm{r}=-.098)$, a significant negative relation at low level between "Future" subdimension ( $\mathrm{r}=-.149)$, a significant negative relation at low level between "University Life 
Quality" ( $\mathrm{r}=-.223)$ and a significant negative relation at low level between "Attitude towards the Profession of Teaching" $(r=-.269)$.

It was found that there was a significant negative relation at low level between "Student Communication Centred Concern" and "Lecturer - Student Communication" sub-dimension $(\mathrm{r}=-.128)$, a significant negative relation at low level between "Identity" sub-dimension ( $\mathrm{r}=$ $.152)$, a significant negative relation at low level between "Future" sub- dimension ( $\mathrm{r}=-.098)$, a significant negative relation at low level between "University Life Quality" ( $\mathrm{r}=-.128)$ and a significant negative relation at low level between "Attitude towards the Profession of Teaching" $(\mathrm{r}=-.213)$.

It was found that there was a significant negative relation at low level between "Colleague Parent Centred Concern" and "Lecturer - Student Communication" sub-dimension ( $\mathrm{r}=-.159)$, a significant negative relation at low level between "Identity" sub-dimension $(r=-.094)$, a significant negative relation at low level between "Social Facilities" sub- dimension ( $\mathrm{r}=-.103)$, a significant negative relation at low level between "University Life Quality" ( $\mathrm{r}=-.093)$ and a significant negative relation at low level between "Attitude towards the Profession of Teaching" $(\mathrm{r}=-.192)$.

It was found that there was a significant negative relation at low level between "Personal Development Centred Concern" and "Lecturer - Student Communication" sub-dimension ( $\mathrm{r}=$ -.154), a significant negative relation at low level between "Identity" sub-dimension ( $\mathrm{r}=-.182)$, a significant negative relation at low level between "University Life Quality" ( $\mathrm{r}=-.141)$ and a significant negative relation at low level between "Attitude towards the Profession of Teaching" $(\mathrm{r}=-.239)$.

It was found that there was a significant negative relation at low level between "Appointment Centred Concern" and "Lecturer - Student Communication" sub-dimension ( $\mathrm{r}=-.093)$, a significant negative relation at low level between "Identity" sub-dimension ( $\mathrm{r}=-.149)$, a significant negative relation at low level between "Future" sub-dimension ( $r=-.093)$ and a significant negative relation at low level between "University Life Quality" ( $r=-.125)$.

It was found that there was a significant negative relation at low level between "Adaptation Centred Concern" and "Lecturer - Student Communication" sub-dimension ( $\mathrm{r}=-.182)$, a significant negative relation at low level between "Identity" sub-dimension $(\mathrm{r}=-.286)$, a significant negative relation at low level between "Involvement in Decisions" sub- dimension $(\mathrm{r}=-.092)$, a significant negative relation at low level between "Student - Student Communication" sub- dimension ( $\mathrm{r}=-.101)$, a significant negative relation at low level between "Future" sub- dimension ( $\mathrm{r}=-.159)$, a significant negative relation at low level between "Classroom Environment" sub- dimension ( $\mathrm{r}=-.100)$, a significant negative relation at low level between "University Life Quality" $(\mathrm{r}=-.240)$ and a significant negative relation at medium level between "Attitude towards the Profession of Teaching" $(\mathrm{r}=-.405)$.

It was found that there was a significant negative relation at low level between "School Administration Centred Concern" and "Lecturer - Student Communication" sub-dimension ( $\mathrm{r}=$ -.173), a significant negative relation at low level between "Student - Student Communication" sub-dimension ( $\mathrm{r}=-.096$ ), a significant negative relation at low level between "University Life Quality" $(\mathrm{r}=-.140)$, and a significant negative relation at low level between "Attitude towards the Profession of Teaching" $(\mathrm{r}=-.084)$. 
It was found that there was a significant negative relation at low level between "Total Professional Concern" and "Lecturer - Student Communication" sub-dimension ( $r=-.199)$, a significant negative relation at low level between "Identity" sub-dimension $(r=-.224)$, a significant negative relation at low level between "Student - Student Communication" subdimension $(\mathrm{r}=-.102)$, a significant negative relation at low level between "Future" subdimension $(r=-.130)$, a significant negative relation at low level between "Classroom Environment" sub-dimension $(\mathrm{r}=-.097)$, a significant negative relation at low level between "University Life Quality" ( $\mathrm{r}=-.197)$, and a significant negative relation at medium level between "Attitude towards the Profession of Teaching" $(\mathrm{r}=-.311)$.

It was found that there was a significant positive relation at low level between "Attitude towards the Profession of Teaching" and "Lecturer - Student Communication" sub-dimension ( $\mathrm{r}=.185)$, a significant positive relation at medium level between "Identity" sub-dimension ( $\mathrm{r}=.310)$, a significant positive relation at low level between "Involvement in Decisions" sub-dimension $(\mathrm{r}=.095)$, a significant positive relation at low level between "Student - Student Communication" sub-dimension $(\mathrm{r}=.139)$, a significant positive relation at low level between "Future" sub-dimension ( $\mathrm{r}=.151)$, a significant positive relation at low level between "Classroom Environment" sub- dimension $(\mathrm{r}=.162)$ and a significant positive relation at low level between "University Life Quality” ( $r=.262)$.

Table 6. The Correlation Between Professional Attitude, Professional Concern and University Life Quality

\begin{tabular}{|c|c|c|c|c|c|c|c|c|c|c|}
\hline & & $\begin{array}{c}\text { Lecturer } \\
- \\
\text { Student } \\
\text { Commun } \\
\text { ication } \\
\end{array}$ & Identity & $\begin{array}{l}\text { Social } \\
\text { Facilities }\end{array}$ & $\begin{array}{l}\text { Involvement } \\
\text { in } \\
\text { Decisions } \\
\text { Making }\end{array}$ & $\begin{array}{l}\text { Student- } \\
\text { Student } \\
\text { Commun } \\
\text { ication }\end{array}$ & Future & $\begin{array}{l}\text { Classro } \\
\text { om } \\
\text { Environ } \\
\text { ment }\end{array}$ & $\begin{array}{l}\text { Total Quality } \\
\text { Life in } \\
\text { University }\end{array}$ & $\begin{array}{l}\text { Attitude } \\
\text { towards the } \\
\text { Profession of } \\
\text { Teaching }\end{array}$ \\
\hline \multirow{2}{*}{$\begin{array}{ll}\text { Task } & \text { Centred } \\
\text { Concern } & \end{array}$} & $r$ & $-.178^{*}$ & $-.185^{*}$ & -.033 & -.021 & $-.092^{*}$ & $-.097^{*}$ & $-.091^{*}$ & $-.155^{*}$ & $-.332^{*}$ \\
\hline & $\mathrm{p}$ & .000 & .000 & .428 & .614 & .027 & .020 & .028 & .000 & .000 \\
\hline \multirow{2}{*}{$\begin{array}{l}\text { Economic-Social } \\
\text { Centred Concern }\end{array}$} & $\mathrm{r}$ & $-.169^{*}$ & $-.254^{*}$ & $-.094^{*}$ & -.064 & $-.098^{*}$ & $-.149^{*}$ & -.073 & $-.223^{*}$ & $-.269^{*}$ \\
\hline & $\mathrm{p}$ & .000 & .000 & .023 & .124 & .019 & .000 & .080 & .000 & .000 \\
\hline \multirow{2}{*}{$\begin{array}{l}\text { Student } \\
\text { Communication } \\
\text { Centred Concern }\end{array}$} & $\mathrm{r}$ & $-.128^{*}$ & $-.152^{*}$ & -.007 & -.019 & -.036 & $-.098^{*}$ & -.080 & $-.128^{*}$ & $-.213^{*}$ \\
\hline & $\mathrm{p}$ & .002 & .000 & .861 & .644 & .387 & .019 & .054 & .002 & .000 \\
\hline \multirow{2}{*}{$\begin{array}{lr}\text { Colleague } & \text { and } \\
\text { Parent } & \text { Centred } \\
\text { Concern }\end{array}$} & $\mathrm{r}$ & $-.159^{*}$ & $-.094^{*}$ & $-.103^{*}$ & -.020 & -.078 & -.079 & -.059 & $-.093^{*}$ & $-.192^{*}$ \\
\hline & $\mathrm{p}$ & .000 & .023 & .013 & .630 & .061 & .057 & .158 & .025 & .000 \\
\hline \multirow{2}{*}{$\begin{array}{l}\text { Personal } \\
\text { Development } \\
\text { Centred Concern }\end{array}$} & $\mathrm{r}$ & $-.154^{*}$ & $-.182^{*}$ & -.012 & -.008 & -.076 & -.079 & -.080 & $-.141^{*}$ & $-.239^{*}$ \\
\hline & $\mathrm{p}$ & .000 & .000 & .768 & .847 & .067 & .056 & .053 & .001 & .000 \\
\hline \multirow{2}{*}{$\begin{array}{l}\text { Appointment } \\
\text { Centred Concern }\end{array}$} & $r$ & $-.093^{*}$ & $-.149^{*}$ & -.044 & -.027 & -.071 & $-.093^{*}$ & -.032 & $-.125^{*}$ & -.028 \\
\hline & $\mathrm{p}$ & .025 & .000 & .293 & .512 & .088 & .025 & .435 & .003 & .504 \\
\hline \multirow{2}{*}{$\begin{array}{l}\text { Adaptation } \\
\text { Centred Concern }\end{array}$} & $\mathrm{r}$ & $-.182^{*}$ & $-.286^{*}$ & -.055 & $-.092^{*}$ & $-.101^{*}$ & $-.159^{*}$ & $-.100^{*}$ & $-.240^{*}$ & $-.405^{*}$ \\
\hline & $\mathrm{p}$ & .000 & .000 & .188 & .027 & .015 & .000 & .016 & .000 & .000 \\
\hline \multirow{2}{*}{$\begin{array}{l}\text { School } \\
\text { Administration } \\
\text { Centred Concern }\end{array}$} & $\mathrm{r}$ & $-.173^{*}$ & -.076 & -.018 & -.063 & $-.096^{*}$ & -.073 & -.077 & $-.140^{*}$ & $-.084^{*}$ \\
\hline & $\mathrm{p}$ & .000 & .069 & .664 & .127 & .021 & .081 & .065 & .001 & .043 \\
\hline \multirow{2}{*}{$\begin{array}{l}\text { Total Professional } \\
\text { Concern }\end{array}$} & $\mathrm{r}$ & $-.199^{*}$ & $-.224^{*}$ & -.003 & -.043 & $-.102^{*}$ & $-.130^{*}$ & $-.097^{*}$ & $-.197^{*}$ & $-.311^{*}$ \\
\hline & $\mathrm{p}$ & .000 & .000 & .949 & .302 & .014 & .002 & .019 & .000 & .000 \\
\hline \multirow{3}{*}{$\begin{array}{l}\text { Attitude towards } \\
\text { the Profession of } \\
\text { Teaching }\end{array}$} & $\mathrm{r}$ & $.185^{*}$ & $.310^{*}$ & .034 & $.095^{*}$ & $.139^{*}$ & $.151^{*}$ & $.162^{*}$ & $.262^{*}$ & \\
\hline & $\mathrm{p}$ & .000 & .000 & .413 & .022 & .001 & .000 & .000 & .000 & \\
\hline & $\mathrm{N}$ & 580 & 580 & 580 & 580 & 580 & 580 & 580 & 580 & \\
\hline
\end{tabular}

$* \mathrm{p}<0.05$ 
Table 7. Multiple Regression Analysis Regarding the Predictive Power of Professional Concern and University Life Quality on Attitudes Toward the Profession of Teaching

\begin{tabular}{cccccccc}
\hline & $\mathrm{B}$ & $\mathrm{t}$ & $\mathrm{p}$ & $\mathrm{F}$ & $\mathrm{p}$ & $\mathrm{R}$ & $\mathrm{R}$ Square \\
\hline Professional Concern & -.161 & 6.882 & .000 & & & & \\
University Life Quality & .285 & 5.309 & .000 & \multirow{2}{*}{46.747} & $.000^{\mathrm{b}}$ & 0.373 & 0.139 \\
\cline { 1 - 3 }
\end{tabular}

As is given Table 7, professional concern and university life quality on explains $13.9 \%$ of the attitude toward the profession of teaching $(\mathrm{R}$ Square $=0.139)$.

\section{Discussion}

It was determined that prospective teachers had a positive professional attitude. The results obtained in their studies by Doğan and Çoban (2009) and Lasek and Wiesenbergová (2007) support this finding. In a study conducted by Kee and Aye (2020), it was found that prospective teachers are willing towards the profession of teaching and they have a strong commitment to the profession of teaching, and they also believe that teaching profession is a noble profession and that it will lead to an esteemed place in the community. Based on these results, it is likely to say that despite all inconveniences mentioned in the introduction, the attitudes of prospective teachers in different countries all over the world towards the profession of teaching are positive.

It was found out that the concern levels of the prospective teachers were low. A study carried out by Sadıkoğlu et al. (2018) determined that the professional concerns of the prospective teachers were low. It was also observed that the prospective teachers had "Appointment Centred Concern" and "Adaptation Centred Concern" the most. In another study carried out by Dilmaç and Topal (2017), it was figured out that a great majority of the prospective teachers (92\%) had appointment concern. A study by Pamuk et al. (2014), pinpointed that prospective teachers had some concerns regarding not being able to find a job, not being able to be appointed, not being able to be successful at public personal selection exam and about family-environment expectations.

It was determined that the satisfaction of the prospective teachers regarding university life quality was at medium level and the dimension they were satisfied at the least level was "Social Facilities". As the research was carried out at a newly founded university, it is thought that the satisfaction levels of the prospective teachers regarding university life quality were at medium level and that they were least satisfied with social facilities. In a study by Kılınç et al. (2017), it was found that physical facilities and socio-cultural and academic activities are among the problems the academic lecturers pointed out regarding the newly founded universities.

It was found that there was a significant positive relation between the attitudes of the prospective teachers towards the profession and the satisfaction level of university life quality and that as the satisfaction level of university life quality increased, so did positive professional attitude. Prospective teachers come from different socio-cultural and socio-economic structures and they choose their profession sometimes on purpose and sometimes unwillingly, consciously or unconsciously; for that reason, they could have different attitudes regarding the profession of teaching. However, it is likely that university life quality increases life satisfaction and level of happiness for the prospective teachers starting their university life and so does positive attitude. In the studies carried out by Siming et al. (2015) and Sirgy et al. (2007), the importance of quality and facilities at higher education was emphasized. In another study carried out by Butt and Rehman (2010), it was found that teacher expertise, recommended courses, learning 
environment and classroom facilities are of role in student satisfaction at higher education institutions. In a study by Akyüz et al. (2017), it was determined that as the life quality of university students increased, their happiness level also increased. In another study conducted by Çatı and Kethüda (2017), it was found that campus life quality affects student satisfaction to a great extent. It was determined that the alienation from faculty is effective on the professional attitudes of the prospective teachers (Erimez \& Gizir, 2013).

It was found that there was a significant negative relation between the professional concerns of the prospective teachers and university life quality and that as the satisfaction level of university life quality increased, professional concern decreased. It is thought that university life quality has an effect upon academic success and professional development positively and accordingly professional concern decreases. It was put an emphasis on the importance of the interaction characteristics of the lecturer, communication style, classroom rules, in-class applications and the applications regarding assessment (Gündoğdu \& Yaşar, 2016), on the effect of facilities upon academic success (Ramli \& Zain, 2018), and on the role of the communication skills of educations upon the academic successes of students (Khan et al., 2017) in the formation of success perception by the students. It was found in another study by Çöğmen and Köksal (2014) that among the cases that the prospective teachers regard it as a handicap for the professional development is insufficiency of university in terms of physical facilities. It was also determined in another study carried out by Topçu and Uzundumlu (2012) that among the factors having an effect on the academic unsuccess at higher education are future concern, insufficiency of physical facilities at the faculty, wrong assessment techniques, insufficiency of application in the field courses and insufficiency in cognitive and behaviours communication.

It was determined that there is a significant negative relation between the professional attitudes of the prospective teachers and their professional concerns and that as the professional concern decreases, positive professional attitude increases. It is thought that the attitude increases in a positive way with the decrease in the distressful feeling felt by the idea of uncertainty, not being able to succeed or experiencing bad events. In a study carried out by Serin (2015), a medium level relation was found between the concern levels of prospective teachers towards the profession of teaching and their attitudes towards the profession of teaching in a negative way. In a study by Doğan and Çoban (2009) carried out with prospective teachers, it was found that there was a significant negative relation at low level between attitude and concern. In another study conducted by Yetişensoy and Şahin (2019), it was found that there were significant negative relations between all sub-dimensions of unemployment concern and the attitude towards the profession of teaching and that there was a significant negative relation at medium level between general unemployment concern of prospective teachers and their attitudes towards the profession of teaching. In a study by Gerçek (2018), it was found that the increase in the concern regarding the profession of teaching decreased the belief in finding a job in the future, being able to overcome the problems to be encountered in career development and being able to adapt to unexpected changes.

It was determined that professional concern and university life quality explains $13.9 \%$ of the attitude toward the profession of teaching. It is likely to say that, professional concern and university life quality predicts attitude toward the profession of teaching at $13.9 \%$ rate based on the fact that there is a negative relation at medium level between professional attitude and professional concern and that there is a significant positive relation at low level between professional attitude and university life quality. In a study carried out by Kalemoğlu et al. (2014), it was found that the variables comprising the sub-dimension of professional concern explained the attitude toward teaching profession significantly. No study was found regarding 
the predictive power of the attitude of university life quality towards the profession of teaching, but in a study carried out by Peker Ünal (2017), it was found that the behaviours of lecturers were effective on the attitudes of prospective teachers towards the profession of teaching. In another study by Shaheen et al. (2016), no significant difference was found in the attitude in terms of program of prospective teachers while there was a difference campus wise. It is thought that a great many variables such as the values of prospective teachers (Kaur, 2017; Parlar \& Cansoy, 2016), their living purposes and psychological well-being levels (İkiz et al., 2018), the sources of self-efficacy beliefs (Arslan \& Çolakoğlu, 2019), self-efficacy perceptions (Ataş Akdemir, 2018; Elald1 \& Yerliyurt, 2016; Kaleli, 2020; Karakuş, 2017), working values (Arastaman \& Demirkasımoğlu, 2017), genders (Kee \& Aye, 2020; Polat, 2019) and thinking styles (Ozan, 2019) affect the attitude towards the profession of teaching. Besides carrying out studies into reducing the professional concerns of the prospective teachers and increasing their university life qualities will affect the professional attitudes of the prospective teachers in a positive way.

\section{Conclusion and Recommendations}

In the current study that was carried out to determine the attitudes of prospective teachers towards the profession of teaching, professional concern and satisfaction level of university life quality, the role of their professional concern and university life quality in explaining their attitudes towards the profession of teaching, it was found that the professional attitudes of the prospective teachers were positive, their professional concern levels were low, they experienced "Appointment Centred Concern" and "Adaptation Centred Concern" the most, their satisfaction regarding university life quality was at medium level and the dimension they were satisfied the least was "Social Facilities".

It was found that there was a significant positive relation between the attitudes of the prospective teachers towards the profession of teaching and the satisfaction level of university life quality and that as the satisfaction level of university life quality increased, so did the positive professional attitude. It was also found that there was a significant negative relation between the professional concerns of the prospective teachers and the satisfaction level of university life quality and that as the satisfaction level of university life quality increased, professional concern decreased. It was concluded that there was a significant negative relation between the attitudes of the prospective teachers towards the profession and their professional concerns and that as the professional concern decreased, positive professional attitude increased. It was determined that professional concern of the prospective teachers and their satisfaction regarding university life quality predicted the attitude towards the profession of teaching at $13.9 \%$ rate.

- It is recommended that various social activities be arranged and some seminars could be given at universities in order to reduce the appointment centres concerns of the prospective teachers to minimum and supports should be given by "Student Guidance and Psychological Consultancy Centres" with regard to the students with a high level of concern.

- In order to reduce the adaptation centred concern levels of the prospective teachers, some elective courses should be opened. It can be of use to carry out interviews between prospective teachers and teacher with the support of Ministry of Education.

- Life qualities of university students should be increased, particularly at newly founded universities, some social domains where prospective teachers could develop themselves 
academically, personally and socially should be formed and social facilities should be increased.

- Other factors (especially media) affecting the attitude towards the profession of teaching could be studied.

- It is recommended to carry out research into determining the expectations of the prospective teachers.

- It is recommended to carry out a similar study with a higher number of sampling and discuss the findings in this regard.

- University life quality could be investigated in different universities, faculties and colleges and the results could be discussed in this direction.

- The current study was carried out in a state university. An alternative approach can be to investigate in the situation with a private university and the results could be compared.

\section{References}

Akinbote, O. (2007). Problems of teacher education for primary schools in Nigeria: Beyond curriculum design and implementation. International Journal of African \& African American Studies, 6(2), 64- 71.

Akyüz, H., Yaşartürk, F., Aydın, İ., Zorba, E., \& Türkmen, M. (2017). Üniversite öğrencilerinin yaşam kalitesi ve mutluluk düzeyleri arasındaki ilişkinin incelenmesi [The investigation of the relationship between university students' levels of life quality and happiness]. International Journal of Cultural and Social Studies, 3, 253-262.

Albareda Tiana, S., García González, E., Jiménez Fontana, R., \& Solís Espallargas, C. (2019). Implementing pedagogical approaches for ESD in initial teacher training at Spanish Universities. Sustainability, 11(4927). https://doi.org/10.3390/su11184927

Ansari, U., \& Malik, S. K. (2013). Image of an effective teacher in 21st century classroom. Journal of Educational and Instructional Studies in the World, 3(4), 61-68.

Arastaman, G., \& Demirkasımoğlu, N. (2017). Öğretmen adaylarının çalışma değerleri ile öğretmenlik mesleğine yönelik tutumları arasındaki ilişki [The relationship between preservice teachers' work values and attitudes toward teaching profession]. Mersin University Journal of the Faculty of Education, 13(2), 650-665. http://dx.doi.org/10.17860/mersinefd.329743

Arslan, Ş., \& Çolakoğlu, Ö. M. (2019). The predictive power of pre-service teachers' sources of self-efficacy beliefs on teaching self-efficacy beliefs and attitudes. Karaelmas Journal of Educational Sciences, 7, 74-83.

Aslan, D., \& Köksal Akyol, A. (2006). Okul öncesi öğretmen adaylarının öğretmenlik mesleğine yönelik tutumları ve mesleki benlik saygılarının incelenmesi [Investigation of the preschool teacher candidates' attitudes towards profession and professional selfrespect]. Journal of Çukurova University Institute of Social Sciences, 15(2), 51-60.

Ataş Akdemir, Ö. (2018). An investigation of the relationship between prospective teachers' self-efficacy beliefs and their attitudes towards teaching profession. Journal of Education and e-Learning Research, 5(3),157-164. https://doi.org/10.20448/journal.509.2018.53.157.164

Atmaca, T. (2020). Öğretmenlerin toplumsal saygınlık ve imajlarına olumsuz etki eden faktörlerin incelenmesi [Examining factors that negatively affect teachers' social dignity and image]. Journal of Education for Life, 34(1), 152-167. https://doi.org/10.33308/26674874.2020341165 
Audu, V. E., \& Egharevba, J. (2016). Undergraduate students' perception and attitudes towards teaching profession in University of Benin, Nigeria. Journal of Educational and Social Research, 6(1), 184-188. https://doi.org/10.5901/jesr.2016.v6n1p184

Aydın, R., \& Sağlam, G. (2012). Öğretmen adaylarının öğretmenlik mesleğine yönelik tutumlarının belirlenmesi (Mehmet Akif Ersoy Üniversitesi örneği) [Teacher applicant's view directed towards to profession of teacher (Example of Mehmet Akif Ersoy University) ]. The Journal of Turkish Educational Science, 10(2), 257-294.

Butt, B., \& Rehman, K. (2010). A study examining the student's satisfaction in higher education. Procedia- Social and Behavioral Sciences, 2, 5446- 5450. https://doi.org/10.1016/j.sbspro.2010.03.888

Büyüköztürk, Ş., Kılıç Çakmak, E., Akgün, Ö. E., Karadeniz, Ş., \& Demirel, F. (2008). Bilimsel araştırma yöntemleri [Scientific research methods]. (2nd Edition). Ankara: Pegem Academy.

Cabı, E., \& Yalçınalp, S. (2013). Öğretmen adaylarına yönelik mesleki kaygı ölçeği (MKÖ): Geçerlik ve güvenirlik çalışması [Occupational anxiety scale for prospective teachers: A study on validity and reliability]. Hacettepe University Journal of Education, 44, 8596.

Çat1, K., \& Kethüda, Ö. (2017). Kampüs yaşam kalitesinin öğrenci memnuniyetine etkisi [The effect of the campus life quality to student satisfaction]. International Multilingual Academic Journal, 3(5), 1-7.

Chand, D. (2015). Major problems and issues of teacher education. International Journal of Applied Research, 1(4), 350-353.

Claudia, C. (2014). The role of extracurricular activities and their impact on learning process. Management, 26(125), 1143-1148.

Cleveland Innes, M. F., \& Emes, C. (2005). Social and academic interaction in higher education contexts and the effect on deep learning. NASPA Journal, 42(2), 241-262.

Çöğmen, S., \& Köksal, N. (2014). Öğretmen adaylarının mesleki gelişimlerini destekleyici üniversite olanakları [University facilities supporting pre-service teachers' proffessional development]. Pamukkale University Journal of Education, 35, 85-98.

Cohen, L., Manion, L., \& Morrison K. (2007). Research methods in education. (6th edition). London and New York: Routledge.

Cotten, S. R., \& Wilson, B. (2006). Student-faculty interactions: Dynamics and determinants. Higher Education, 51(4), 487-519.

de la Harpe, B., \& Radloff, A. (1999). Helping future teachers to be effective learners: Providing in context learning support for first year teacher education students. Australian Journal of Teacher Education, 24(2). http://dx.doi.org/10.14221/ajte.1999v24n2.3

Demirtaş, H., Cömert, M., \& Özer, N. (2011). Öğretmen adaylarının özyeterlik inançları ve öğretmenlik mesleğine ilişkin tutumları [Pre-service teachers' self-efficacy beliefs and attitudes towards profession]. Education and Science, 36(159), 96-111.

Dilmaç, O., \& Topal, G. (2017). Görsel sanatlar öğretmeni adaylarının mesleki kaygılarına ilişkin görüşlerinin belirlenmesi [Identifying the views of prospective visual arts teachers on their professional anxieties]. Ahi Evran University Journal of Kirsehir Faculty of Education, 18(1), 383-403.

Doğan, T., \& Çoban, A. E. (2009). Eğitim fakültesi öğrencilerinin öğretmenlik mesleğine yönelik tutumları ile kaygı düzeyleri arasındaki ilişkinin incelenmesi [The investigation of the relations between students' attitude toward teaching profession and anxiety level in faculty of education]. Education and Science, 34(153), 157-168.

Doğanay, A., \& Sarı, M. (2006). Öğrencilerin üniversitedeki yaşam kalitesine ilişkin algılarının demokratik yaşam kültürü çerçevesinde değerlendirilmesi (Çukurova Üniversitesi 
örneği) [Evaluation of students' perceptions about quality of life in their campus in terms of democratic life culture (Çukurova University case)]. The Journal of Turkish Educational science, 4(2), 107-128.

Elaldı, Ş., \& Yerliyurt, N. S. (2016). Preservice preschool teachers' self-efficacy beliefs and attitudes toward teaching profession. Educational Research and Reviews, 11(7), 345357. https://doi.org/10.5897/ERR2016.2648

Engin, G., \& Koç, G. (2014). Öğretmen adaylarının öğretmenlik mesleğine yönelik tutumları (Ege Üniversitesi Eğitim Fakültesi örneği) [The attitudes of prospective teachers towards teaching (The case of Ege University, faculty of education)]. Turkish Journal of Social Research, 18(2), 153-167.

Erimez, C., \& Gizir, S. (2013). Eğitim Fakültesi öğrencilerinin öğretmenlik mesleğine yönelik tutumlarında fakültelerine yabancılaşmalarının rolü [The role of faculty of education students' alienation to their faculty on the attitudes towards teaching profession]. Mersin University Journal of the Faculty of Education, 9(3), 13-26.

Eriş, H. M., \& Anıl, D. (2016). Üniversite öğrencilerinin yaşam kalitesi düzeylerinin bazı değişkenlere göre incelenmesi [An examination of the levels of university student's quality of life in terms of some variables]. Hacettepe University Journal of Education, 31(3), 491-504. https://doi.org/10.16986/HUJE.2015014183

Erzen, Z., \& Epçaçan, C. (2018). Öğretmen görüşlerine göre öğretmenlerin toplumdaki saygınlığının incelenmesi [Examination of teacher's respectability in society according to teacher's opinions]. Journal of Institute of Economic Development and Social Researches, 4(9), 331-345.

Foubert, J. D., \& Grainger, L. U. (2006). Effects of involvement in clubs and organizations on the psychosocial development of first-year and senior college students. NASPA Journal, 43(1), 166-182. https://doi.org/10.2202/1949-6605.1576

Fuller, F. F. (1969). Concerns of teachers: A developmental conceptualization. American $\begin{array}{llll}\text { Educational } \quad \text { Research } & \text { 207-226. }\end{array}$ https://doi.org/10.3102/00028312006002207

Gerçek, M. (2018). Mesleki kaygı ve kariyer uyumluluğu arasındaki ilişkiler: Öğretmen adayları açısından bir inceleme [The relationships between occupational anxiety and career adaptability: A study on pre-service teachers]. Trakya University Journal of Social Science, 20(2), 297-312. https://doi.org/10.26468/trakyasobed.401010

Girgin, G., Özyılmaz Akamca, G., Ellez, A. M., \& Oğuz, E. (2010). Okul öncesi öğretmen adaylarının öğretmenlik mesleğine yönelik tutumları, mesleki benlik saygıları ve mesleki yeterlik inançları [Preschool teacher candidates' attitudes towards profession, sel efficacy beliefs and professional self respects]. The Journal of Buca Faculty of Education, 28, 1-15.

Gökçe, F., \& Sezer, G. O. (2012). Öğretmen adaylarının öğretmenlik mesleğine yönelik tutumları (Uludağ Üniversitesi Örneği) [The attitudes of student teachers towards teaching profession (Uludag University sample)]. Journal of Uludağ University Faculty of Education, 25(1), 1-23.

Göktaş Kulualp, H., \& Erol, S. (2018). Üniversite öğrencilerinin motivasyonunda sosyal etkinliklerin önemi [The importance of social activities in the motivation of university students]. Journal of the Human and Social Science Researches, 7(3), 1592-1611.

Gündoğdu, S., \& Yaşar, M. (2016). Öğretim eleman1- öğrenci arasındaki örtük ilişkiler ile öğrencilerin başarı algıları arasındaki ilişki [Relations of students' success perceptions and implicit relations between instructor-student]. Milli Ĕgitim, 212, 81-92.

Hagenauer, G., Gläser Zikuda, M., \& Volet, S. E. (2016). University teachers' perceptions of appropriate emotion display and high-quality teacher-student relationship: similarities 
and differences across cultural-educational contexts. Frontline Learning Research, 4(3), 44-74. http://dx.doi.org/10.14786/flr.v4i3.236

Hagenauer, G., \& Volet, S. E., (2014). Teacher-student relationship at university: An important yet under- researched field. Oxford Review of Education, 40(3), 370-388. https://doi.org/10.1080/03054985.2014.921613

Himmat, D. (2017). Challenges and remedy of teacher education. Global Science Reserach Journals, 5(1), 77-81.

Hu, Y. L., Hung, C. H., \& Ching, G. S. (2015). Student-faculty interaction: Mediating between student engagement factors and educational outcome gains. International Journal of Research Studies in Education, 4(1), 43-53. https://doi.org/10.5861/ijrse.2014.800

İkiz, F. E., Asıcı, E., \& Kaya, Z. (2018). Yaşam amaçları ve psikolojik iyi oluşun öğretmenlik mesleğine yönelik tutumu yordayıcı rolü [The predictive roles of life goals and psychological well- being on attitudes towards teaching profession]. Journal of Bayburt Education Faculty, 13(25), 7-26.

İnceoğlu, M. (2010). Attitude perception communication. (5th edition). İstanbul: Beykent University Publishing.

Kaleli, Y. S. (2020). Investigation of the relationship between pre-service music teachers' attitudes towards teaching profession and their self-efficacy beliefs. International Journal of Research in Education and Science, 6(4), 580-587.

Kalemoğlu Varol, Y., Erbaş, M. K., \& Ünlü, H. (2014). Beden eğitimi öğretmen adaylarının mesleki kaygı düzeylerinin öğretmenlik mesleğine yönelik tutumlarını yordama gücü [The predictive power of occupational anxiety levels of prospective physical education teachers upon their attitudes towards the teaching profession]. SPORMETRE The Journal of Physical Education and Sport Sclences, 12(2), 113-123. https://doi.org/10.1501/Sporm_0000000259

Kangal, A. (2012). Üniversite yaşam kalitesi ölçeğinin Türkçe uyarlaması: Geçerlik ve güvenirlik çalışması [Adaptation of the quality of college life (QCL) Measure to Turkish: A validity and reliability study]. e-International Journal of Educational Research, 3(1), 16-32.

Karakuş, İ. (2017). Öğretmen adaylarının öz yeterlik algıları ile öğretmenlik mesleğine yönelik tutumlarının incelenmesi [Pre-service teachers' self-efficacy beliefs and attitudes towards profession]. The Journal of Kesit Academy, 9, 361-377.

Karamustafaoğlu, O., \& Özmen, H. (2004). Toplumumuzda ve öğretmen adayları arasında öğretmenlik mesleğine verilen değer üzerine bir araştırma [An investigation of the value of teaching profession among teacher-candidates and Turkish society]. Journal of Values Education, 2(6), 35-49.

Karataş, K., Ardıç, T., \& Oral, B. (2017). Öğretmenlik mesleğinin yeterlikleri ve geleceği: Metaforik bir analiz [Teaching profession's competencies and its future: A metaphorical analysis]. Electronic Turkish Studies, 12(33), 291-312. http://dx.doi.org/10.7827/TurkishStudies.12665

Kaur, B. (2017). Social and economic values of prospective teachers in relation to attitude towards teaching profession. International Education \& Research Journal, 3(5), 167168.

Kayhan, A., Baysan, O., \& Alcı, B. (2018). Öğretmen adaylarının öğretmenlik mesleğine yönelik tutumlarının farklı değişkenler açısından incelenmesi [An investigating of prospective teachers' attitudes regarding teaching various variables]. The Journal of Academic Social Science, 6(72), 545-559.

Kee, B., \& Aye, S. (2020). A study of the attitude of pre-service teachers in education colleges towards their teaching profession. J. Myanmar Acad. Arts Sci., 18(9C), 457-472. 
Khan, A., Khan, S., Zia Ul Islam, S., \& Khan, M. (2017). Communication skills of a teacher and its role in the development of the students' academic success. Journal of Education and Practice, 8(1), 18-21.

Kılınç, A. Ç., Çepni, O., Kılcan, B. \& Palaz, T. (2017). Öğretim üyelerinin görüşlerine göre Türkiye'de yeni kurulan üniversitelerin sorunları: Nitel bir araştırma [Problems of recently founded universities in Turkey according to the views of faculty members: A qualitative study]. Journal of Higher Education and Science, 7(2), 282-293. https://doi.org/10.5961/jhes.2017.207

König, J., Ligtvoet, R., Klemenz, S., \& Rothland, M. (2017). Effects of opportunities to learn in teacher preparation on future teachers' general pedagogical knowledge: Analyzing program characteristics and outcomes. Studies in Educational Evaluation, 53, 122-133. http://dx.doi.org/10.1016/i.stueduc.2017.03.001

Kumar, P., \& Azad, S. (2016). Teacher education in India: Some policy issues and challenges. International Journal of Advance Research and Innovative Ideas in Education, 2(6), 1217-1224.

Lasek, J., \& Wiesenbergova, S. (2007). Prospective teachers' attitudes to their profession. The New Educational Review, 13(3-4), 129-136.

Manolova Yalçın, O., \& Özgen, B. (2017). Okul öncesi öğretmenliği bölümü öğrencilerinin mesleğe yönelik tutumlarının ve öz güven düzeylerinin incelenmesi (KKTC) [The examination of pre-school teacher candidates' attitudes towards the profession and selfconfidence levels (TRNC)]. Journal of Education, Theory and Practical Research, 3(3), 63-80.

Mazmishvili, N., Tavdgiridze, L., \& Doborjginidze, D. (2019). The challenge of teacher-parent collaboration in Georgia. 5th International Conference on Social, Economic, and Academic Leadership (ICSEALV 2019), 159-165. Atlantis Press. Advances in Social Science, Education and Humanities Research, 386, 159-165. https://doi.org/10.2991/assehr.k.191221.193

Mullai, E. (2017). The role of teachers supports the rapid development of society. European Journal of Research and Reflection in Educational Sciences, 5(6), 1-6.

Nakip, C., \& Özcan, G. (2016). Öğretmen adaylarının öğretmenlik mesleğine yönelik özyeterlik inançları ile öğretmenlik mesleğine yönelik tutumları arasındaki ilişki [The relation between preservice teachers' sense of self efficacy and attitudes toward teaching profession]. Mersin University Journal of the Faculty of Education, 12(3), 783795. http://dx.doi.org/10.17860/mersinefd.282380

Nalçacı, A., \& Sökmen, Y. (2016). Öğretmen adaylarının mesleği tercih nedenleri ve öğretmenlik mesleğine yönelik tutumları arasındaki ilişki [The reasons for pre-service teachers to prefer teaching profession and its relationship with their attitudes toward this profession]. Ahi Evran University Journal of Kirsehir Faculty of Education, 17(3), 717727.

Oğuz, E., \& Kalkan, M. (2011). Examining teacher candidates' attitudes towards teaching profession and pupil control ideology. International Online Journal of Educational Sciences, 3(3), 903-917.

Ozan, C. (2019). The relationship between prospective teachers' thinking styles and attitudes towards teaching profession. Journal of Curriculum and Teaching, 8(3), 50-62. http://dx.doi.org/10.5430/jct.v8n3p50

Özder, H., Konedralı, G., \& Zeki, C. P. (2010). Öğretmen adaylarının öğretmenlik mesleğine yönelik tutumlarının çeşitli değişkenler açısından incelenmesi [Examining the attitudes towards the teaching profession and academic achievements of prospective teachers]. Educational Administration: Theory and Practice, 16(2), 253-275. 
Pamuk, Y., Hamurcu, H., \& Armağan, B. (2014). Sınıf öğretmeni adaylarının durumluk ve sürekli kaygı düzeylerinin incelenmesi) (İzmir-Buca örneği) [Examination of situational and continuous anxiety level of classroom teachers candidates (Izmir - Buca sample)]. Bartin University Journal of Faculty of Education,3(2), 293-316. https://doi.org/10.14686/BUEFAD.201428183

Parlar, H., \& Cansoy, R. (2016). Öğretmen adaylarının öğretmenlik mesleğine yönelik tutumlarının bir yordayıcısı olarak bireysel değerler [Personal values as a predictor of prospective teachers' attitude towards teaching profession]. Marmara University Atatürk Education Faculty Journal of Educational Sciences, 44, 125-141.

Peker Ünal, D. (2017). Öğretmen adaylarının mesleğe yönelik tutumlarını etkileyen örtük bir öge olarak öğretim üyesi davranışları [Academician behaviours as an implicit element affecting the attitudes of teacher nominees towards their professions]. Journal of Higher Education and Science, 7(3), 430- 440. https://doi.org/10.5961/jhes.2017.220

Picton, C., Kahu, E. R., \& Nelson, K. (2017). Friendship supported learning - the role of friendships in first-year students' university experiences. In Proceedings of STARS: Students Transitions Achievement Retention and Success Conference. Adelaide, Australia: STARS.

Polat, Ü. (2019). The effects of genders of prospective teachers on their attitudes towards teaching profession: A meta-analysis. Pedagogical Research, 4(1), em0027. https://doi.org/10.29333/pr/5732

Ramli, A., \& Zain, R. M., (2018). The impact of facilities on student's academic achievement. Sci. Int. (Lahore), 30(2), 299-311.

Riaz, M., Habib, Z., Riaz, J., \& Uzair ul Hassan, M. (2015). Comparing professional attitude of prospective teachers enrolled in public and private institutions in Punjab. Pakistan Vision, 16(1), 274-291.

Ries, F., Cebrera, C., \& Carriedo, R. (2016). A study of teacher training in the United States and Europe. The European Journal of Social and Behavioural Sciences, 17. http://dx.doi.org/10.15405/ejsbs.184

Sadıkoğlu, M., Hastürk, G., \& Polat, O. (2018). Fen bilimleri öğretmen adaylarının mesleki kayg1 düzeyleri [Examination of science prospective teachers' occupational anxiety levels]. The Journal of International Social Research, 11(56), 629-637. http://dx.doi.org/10.17719/jisr.20185639035

Şahan, G. (2016). Analysis of the problems encountered in education of teachers and solution recommendations in accordance with the opinions of faculty of education students. International Journal of Environmental \& Science Education, 11(5), 10551064. https://doi.org/10.12973/ijese.2016.409a

Şahin, C., \& Şahin, S. (2017). Öğretmen adaylarının öğretmenlik mesleğine yönelik tutumları, öz-yeterlik inançları ve öğrenciyi tanıma düzeyleri [Pre-service teachers' attitudes towards the profession of teaching, self-efficacy beliefs and level of knowing students]. The Journal of Turkish Educational science, 15(2), 224-238.

Serin, M. K., Güneş, A. M., \& Değirmenci, H. (2015). Sınıf öğretmenliği bölümü öğrencilerinin öğretmenlik mesleğine yönelik tutumları ile mesleğe yönelik kaygı düzeyleri arasındaki ilişki [The relationship between the attitudes towards teaching profession and the anxiety level of prospective primary school teachers]. Cumhuriyet International Journal of Education, 4(1), 21-34.

Shaari, A. S., Yusoff, N. M., Ghazali, I. M., Osman, R. H., \& Dzahir, N. F. M. (2014). The relationship between lecturers' teaching style and students' academic engagement. Procedia-Social and Behavioral Sciences, 118, 10-20. https://doi.org/10.1016/j.sbspro.2014.02.002 
Shaheen, F., Kashif, F. M., Daud, H., \& Tariq, M. (2016).Exploring the attitude of prospective teachers towards teaching profession. The Sindh University Journal of Education, 45(2), 29-43.

Siming, L., Gao, J., \& Xu, D. (2015). Factors leading to students' satisfaction in the higher learning institutions. Journal of Education and Practice, 6(31), 114-118.

Singh, L., \& Shakir, M. (2019). Teacher education: Issues and concerns in current scenario. International Journal of Research and Analytical Reviews, 6(2), 1082-1091.

Sirgy, M. J., Grzeskowiak, S., \& Rahtz, D. (2007). Quality of college life (QCL) of students: Developing and validating a measure of well-being. Social Indicators Research, 80, 343-360. https://doi.org/10.1007/s11205-005-5921-9

Stephens, P., Tonnessen, F. E., \& Kyriacou, C. (2004). Teacher training and teacher education in England and Norway: A comparative study of policy goals. Comparative education, 40(1), 109-130. https://doi.org/10.1080/0305006042000184908

Sykes, G., Bird, T., \& Kennedy, M. (2010). Teacher education: Its problems and some prospects. Journal of Teacher Education, 61(5), 464-476. https://doi.org/10.1177/0022487110375804

Tiwari, M. (2016). Teacher education: Problems and suggestions. International Journal of Multidisciplinary Education and Research, 1(1), 28-30.

Topcu, Y., \& Uzundumlu, A. S. (2012). Yüksek öğretimde öğrencilerin başarısızlığına etki eden faktörlerin analizi [The analysis of the factors affecting the students' failure in higher education]. I $\breve{g} d \imath r$ Univ. J. Inst. Sci. \& Tech., 2(2),51-58.

Ujlakyné Szucs, É. (2009). The role of teachers in the 21 st century. Sens public. https://doi.org/10.7202/1064225ar

Ünal, K., \& Akay, C. (2017). Öğretmenlik mesleği ve yaşam boyu öğrenme: Öğretmen adayları penceresinden [Teaching profession and lifelong learning: from the perspective of teacher candidates]. Mersin University Journal of the Faculty of Education, 13(3), 821838. http://dx.doi.org/10.17860/mersinefd.339943

Üstüner, M. (2006). Öğretmenlik mesleğine yönelik tutum ölçeğinin geçerlik ve güvenirlik çalışması [Reliability and validity study of an attitude scale of teaching profession]. Educational Administration: Theory and Practice, 45, 109-127.

Uyanık, G. (2017). Sınıf öğretmeni adaylarının öğretmenlik mesleğine yönelik tutumlarının çeşitli değiş̧kenler açısından incelenmesi: Boylamsal bir araştırma [Investigation of the prospective classroom teachers' attitudes towards teaching profession in terms of various variables: A longitudinal research]. Karaelmas Journal of Educational Sciences, 5, 196-206.

Walliman, N. (2017). Research methods: The basics. Routledge.

Yetişensoy, O., \& Şahin, İ. F. (2019). Sosyal bilgiler öğretmen adaylarının işsizlik kaygısı düzeyleri ile öğretmenlik mesleğine ilişkin tutumları arasındaki ilişkinin incelenmesi [Investigation of the relationship between social studies teacher candidate's unemployment worries and their attitudes toward teaching profession]. Hacettepe University Journal of Education, Advance online publication. https://doi.org/10.16986/HUJE.2019053983 